\title{
Effect of karst rocky desertification on soil fungal communities in Southwest China
}

\author{
P.C. Wang ${ }^{1 *}$, B.T. Mo ${ }^{1 *}$, Y. Chen ${ }^{1}$, Q.F. Zeng ${ }^{1}$ and L.B. Wang ${ }^{2}$ \\ ${ }^{1}$ Guizhou Institute of Prataculture, Guiyang, China \\ ${ }^{2}$ Research Institute of Forestry, Chinese Academy of Forestry, Beijing, China \\ *These authors contributed equally to this study. \\ Corresponding author: L.B. Wang \\ E-mail: wlibing@163.com
}

Genet. Mol. Res. 15 (3): gmr.15038460

Received January 19, 2016

Accepted March 18, 2016

Published July 29, 2016

DOI http://dx.doi.org/10.4238/gmr.15038460

Copyright (C) 2016 The Authors. This is an open-access article distributed under the terms of the Creative Commons Attribution ShareAlike (CC BY-SA) 4.0 License.

\begin{abstract}
Karst mountainous ecosystems are associated with karst rocky desertification (KRD), which can greatly impact soil structure and function. Despite the importance of soil microbes as a major factor maintaining ecosystem stability, we know little about the effect on soil fungal communities of KRD in karst regions. We investigated this relationship across a gradient of KRD soils from Guizhou, China by polymerase chain reaction and denaturing gradient gel electrophoresis (PCR-DGGE). Fungal diversity indices (Shannon-Wiener, richness, and evenness) significantly differed $(\mathrm{P}<0.05)$ based on KRD severity, being lowest in moderately affected areas. Cluster analysis showed that the five sites examined clustered into two main groups according to KRD grade (high and low). Moreover, a homology search using sequences recovered from PCR-DGGE bands showed that the dominant fungi in each community varied remarkably, and included Aspergillus, Aphanoascus, Blastomyces, Fusarium, Glomus, Geomyces, Gibberella,
\end{abstract}


Mortierella, Tetracladium, and Tumularia species, and an unclassified group. In conclusion, these findings demonstrate that KRD has a significant impact on soil fungal communities.

Key words: Fungi; PCR-DGGE; Karst; Rocky desertification; 18S rRNA

\section{INTRODUCTION}

Karst mountainous regions are fragile environments highly sensitive to change. The karst mountainous region of Southwest China, an area spanning approximately 540,000 $\mathrm{km}^{2}$, is among the world's three largest continuous karst regions (Huang et al., 2009; Qi et al., 2013; Yang et al., 2013). Over the past decades, inappropriate agricultural practices and over-exploitation of sloping lands have caused these areas to suffer greatly from karst rocky desertification (KRD), resulting in severe soil erosion and widespread exposure of basement rocks (Wu et al., 2011). KRD events can have a large impact on the structure and functioning of ecosystems through a variety of effects on soil, including structure deterioration, texture and porosity degeneration, decline in water capacity, and leanness (Huang et al., 2009; Peng et al., 2013; Tang et al., 2013). Therefore, these events may lead to serious economic constraints on the development of affected regions. Research on changes to soil structure in typical KRD regions has been limited to the study of basic physical and chemical properties (Zhou et al., 2012; Peng et al., 2013; Tang et al., 2013). Few studies, however, have investigated the effect on soil microbes.

Soil microbes play key roles in controlling land degradation processes such as soil loss, nutrient depletion, and reduced water holding capacity (Bossio et al., 2005; Souza et al., 2014). Several aspects of microbial activity have been proposed as soil quality measures due to their sensitivity, and have been used as bioindicators of degradation processes (Ros et al., 2003, 2009). Fungi are a fundamental component of soil microbial communities (Hagn et al., 2003; Orlandelli et al., 2012), and play important roles in many essential processes, including organic matter decomposition, elemental release by mineralization, and protection against leaching by elemental storage in biomass (Hagn et al., 2003; Malosso et al., 2006; Premalatha et al., 2015). Moreover, their mycelia contribute to soil aggregate stability, thereby preventing erosion (Rao et al., 2012). Therefore, changes in the composition of the fungal community can be used to assess soil quality, and research into such alterations may provide helpful information to assess the effectiveness of ecological restoration in karst regions. However, little is known about the relationship between soil fungal communities and KRD in karst mountainous regions exposed to considerable human activity.

Polymerase chain reaction coupled with denaturing gradient gel electrophoresis (PCR-DGGE) has been widely used to determine the species richness and structure of fungal communities in a variety of environments (Sigler and Turco, 2002; Costa et al., 2006; Yu et al., 2013; Zhang et al., 2013; Dieng et al., 2014). Primarily, this technique is carried out by amplifying specific sequences of interest, such as ribosomal RNA (rRNA) genes (Cahyani et al., 2004; Zhao et al., 2012; Yan et al., 2013; Yoshitake et al., 2013). It is a quicker and less labor-intensive approach than sequencing clone libraries for comparing

Genetics and Molecular Research 15 (3): gmr.15038460 
community composition across samples (Oros-Sichler et al., 2006; Liang et al., 2008). Besides, PCR-DGGE enables the detection of unculturable microorganisms and is better suited to the investigation of soil microbial diversity (Liang et al., 2008; Yan et al., 2013; Yoshitake et al., 2013; Najnin et al., 2015). Therefore, it also formed an important part of this study.

In order to address the relative lack of knowledge regarding the diversity and composition of soil fungal communities in karst ecosystems affected by KRD, our study aimed to characterize the relationship between soil fungi and KRD severity in the karst mountainous region of Southwest China.

\section{MATERIAL AND METHODS}

\section{Field surveys and soil sampling}

Five areas affected by typical degrees of KRD were selected in October 2014 at experimental sites established in Puding County, Guizhou Province, Southwest China. Puding has a northern subtropical wet monsoon climate with a mean annual temperature of $15.1^{\circ} \mathrm{C}$ (minimum and maximum monthly mean temperatures are $5.2^{\circ} \mathrm{C}$ in January and $23^{\circ} \mathrm{C}$ in July, respectively), and an annual rainfall of $1374.3 \mathrm{~mm}$, of which 83.6-90.2\% falls in May-October. The terrain surface undulates lightly, with an average slope of $6.9^{\circ}$. The average elevation is $1291 \mathrm{~m}$, with a maximum height of $1551 \mathrm{~m}$ and a minimum of $1219 \mathrm{~m}$. Yellow soil is the main soil type. Various types of natural vegetation are present, with evergreen and deciduous broadleaved forest predominating (Zhang et al., 2010).

Xiong et al. (2002) proposed classification of KRD based on four factors: vegetation $(\%)$, slope $\left({ }^{\circ}\right)$, bare rock $(\%)$, and average topsoil depth $(\mathrm{cm})$. According to these factors, we chose five sites representing typical KRD grades, namely, A) potential, B) slight, C) moderate, D) strong, and E) extremely strong. Basic characteristics of the selected sites and the dominant species present are described in Table 1.

\section{Table 1. Description of the selected karst rocky desertification (KRD) sites.}

\begin{tabular}{l|c|c|c|l}
\hline KRD type & Code & Exposed rock (\%) & Vegetation coverage (\%) & Land use/type (dominant species) \\
\hline Potential & $\mathrm{A}$ & $20-30$ & $80-70$ & Sloping cropland (maize + soybean intercropping) \\
\hline Slight & $\mathrm{B}$ & $31-50$ & $69-50$ & $\begin{array}{l}\text { Shrubland (Coriaria sinica }+ \text { Cotoneaster adpressus }+ \text { Rosa cymosa }+ \\
\text { Pyracantha fortuneana) }\end{array}$ \\
\hline Moderate & $\mathrm{C}$ & $51-70$ & $49-30$ & $\begin{array}{l}\text { Middle-coverage grassland (Themeda japonica }+ \text { Eremochloa ophiuroides }+ \\
\text { Arthraxon hispidus) }\end{array}$ \\
\hline Strong & $\mathrm{D}$ & $71-90$ & $29-10$ & Shikala land* (maize monoculture) \\
\hline Extremely strong & $\mathrm{E}$ & $>90$ & $<10$ & $\begin{array}{l}\text { Deserted shikala land (Digitaria sanguinalis }+ \text { Bidens bipinnata }+ \text { Conyza } \\
\text { canadensis) }\end{array}$ \\
\hline
\end{tabular}

*In most KRD regions, the remaining cultivated fields are extremely small in size, dotted irregularly among exposed rocks and in fissures; this is referred to as shikala land (Li et al., 2009).

For each sampling site, five to eight cores were taken from surface soil $(0-15 \mathrm{~cm})$ using a $3-\mathrm{cm}$ diameter auger along an S-shaped transect, before being bulked and mixed as a single soil sample. Each soil sample was kept in sealed plastic bag at $4^{\circ} \mathrm{C}$ and immediately transferred to $-70^{\circ} \mathrm{C}$ storage after transportation to the laboratory, where they remained until used for determination of fungal phylogenetic diversity. 


\section{Soil DNA extraction}

To extract total microbial DNA from soil, $5 \mathrm{~g}$ each sample was used for genomic DNA isolation. Total genomic DNA was extracted and purified using a PowerSoil DNA Isolation Kit (MO BIO, Carlsbad, CA, USA) following the manufacturer protocol. The quality and quantity of genomic DNA was examined by agarose gel electrophoresis and using a NanoDrop 1000 spectrophotometer (NanoDrop Technologies, Wilmington, DE, USA), respectively.

\section{PCR}

Amplification of 18S rRNA genes was conducted with the primers GC-Fung and NS1 (Table 2). The $25-\mu \mathrm{L}$ reaction mixture contained $50 \mathrm{ng}$ template DNA (a $50 \mathrm{X}$ dilution of extracted DNA), $10 \mathrm{mM}$ each primer, $2.5 \mathrm{mM}$ each deoxynucleotide, $1 \mathrm{X}$ Taq buffer ( $200 \mathrm{mM}$ Tris-HCl, $\mathrm{pH}$ 8.4, and $500 \mathrm{mM} \mathrm{KCl}$ ), and 2.0 U Taq DNA polymerase (Invitrogen, Waltham, MA, USA). Amplification conditions consisted of a long denaturation at $94^{\circ} \mathrm{C}$ for $5 \mathrm{~min}$, before 30 cycles of $94^{\circ} \mathrm{C}$ for $30 \mathrm{~s}, 60^{\circ} \mathrm{C}$ for $30 \mathrm{~s}$, and $72^{\circ} \mathrm{C}$ for $15 \mathrm{~s}$. This was followed by a single extension step at $72^{\circ} \mathrm{C}$ for $10 \mathrm{~min}$.

Table 2. Primers used for amplification of $18 \mathrm{~S}$ ribosomal RNA genes.

\begin{tabular}{l|l}
\hline Primer & Sequence (5'-3') \\
\hline NS1 & GTA GTC ATA TGC TTG TCT C \\
\hline Fung & CAT TCC CCG TTA CCC GTT G \\
\hline GC-Fung & CGC CCG CCG CGC CCC GCG CCC GGC CCG CCG CCC CCG CCC CAT \\
& TCC CCG TTA CCC GTT G \\
\hline
\end{tabular}

Amplified PCR products were separated by $1 \%$ agarose gel electrophoresis. DNA fragments of the correct size were excised from the gel and purified using a TIANgel Midi Purification Kit (TIANGEN, Beijing, China) following the manufacturer protocol. Gelpurified amplicons were verified by $1 \%$ agarose gel electrophoresis.

\section{DGGE analysis}

The DCode Universal Mutation Detection System (Bio-Rad, Hercules, CA, USA) was used to generate DGGE fingerprints. An $8-\mu \mathrm{L}$ aliquot of each purified PCR product was loaded on a $16 \times 16-\mathrm{cm}$ DGGE gel, comprising $8 \%$ polyacrylamide $(\mathrm{w} / \mathrm{v})$ and a $35-60 \%$ denaturing gradient of urea plus formamide. The products were resolved by electrophoresis in $1 \mathrm{X}$ Trisacetate-ethylenediaminetetraacetic acid (TAE) buffer at $60^{\circ} \mathrm{C}$ under a constant voltage of 60 $\mathrm{V}$ for $12 \mathrm{~h}$. Gels were stained for $30 \mathrm{~min}$ in $1 \mathrm{X}$ TAE buffer containing SYBR Green I (Sigma, St. Louis, MO, USA), and visualized by ultraviolet transillumination (Gel Doc; Bio-Rad). The position and intensity of each band were determined using the Quantity One software v4.62 (Dice, 1945; Tang et al., 2013).

Cluster analysis of DGGE banding patterns was performed automatically by the Quantity One software. Similarities among soil samples were displayed graphically as

Genetics and Molecular Research 15 (3): gmr.15038460 
a dendrogram. The clustering algorithm used to calculate the dendrogram employed an unweighted pair group method with arithmetic mean, based on the Dice coefficient. Diversity of soil fungus communities was evaluated using the Shannon-Wiener index $(H)$, richness $(S)$, and evenness $\left(E_{H}\right)$, based on Equations 1 and 2, as follows (Saikaly et al., 2005):

$$
\begin{gathered}
H=-\sum_{i=1}^{S} P i \ln P i \\
E_{H}=H / H_{\text {max }}=H / \ln S
\end{gathered}
$$

(Equation 1)

(Equation 2)

where $P i$ is the ratio of the intensity of a single band to the total intensity of all bands within the same lane, and $S$ is the total number of bands in each lane.

\section{Sequencing and phylogenetic affiliation}

From the DGGE profiles, unique bands and one common band were selected for sequencing. The selected gene sequences were aligned against those of reference strains using the Basic Local Alignment Search Tool (http://www.ncbi.nlm.nih.gov/). All sequences recovered from DGGE bands and those of their closest reference strains were included in a maximum likelihood phylogenetic analysis carried out using PhyML v3.0. The general timereversible + gamma distribution + invariant sites substitution model was chosen on the basis of the Akaike information criterion implemented in jModelTest 2 (Guindon et al., 2010; Darriba et al., 2012). Settings used in PhyML were as follows: BioNJ starting tree, four substitution rate categories, estimated proportion of invariable sites, and subtree pruning and regrafting and nearest neighbor interchange tree improvement algorithms. To assess support, 1000 nonparametric bootstrap replicates were used. Trees were drawn using the MEGA5 software (Saitou and Nei, 1987; Tamura et al., 2011; Tang et al., 2013).

\section{RESULTS}

\section{Fungal diversity indices}

We analyzed PCR-DGGE profiles of soil fungal communities at sites of potential, slight, moderate, strong, and extremely strong KRD in Guizhou, China. Fungi-specific amplification of 18S rRNA genes with GC-Fung and NS1 primers gave a clear PCR product of the expected size for all soil samples under investigation. The DGGE patterns exhibited differences between sites regarding the number, intensity, and migration rate of bands, suggesting shifts in fungal community structure in the bulk soils (Figure 1).

Each soil fungal diversity index $\left(H, S\right.$, and $\left.E_{H}\right)$ showed the same varying trend as KRD grade increased (Figure 2). During the rocky desertification process, fungal diversity increased under slight KRD, but demonstrated the lowest values at the moderately affected site, showing the least complex banding pattern. Under strong KRD, all fungal diversity indices began to rise. Significant differences in the three indices were detected between degrees of KRD (P $<0.05$ ). Moreover, measures of fungal diversity were lowest at the site of moderate KRD, indicating that this is an unstable stage in the karst ecosystem.

Genetics and Molecular Research 15 (3): gmr.15038460 


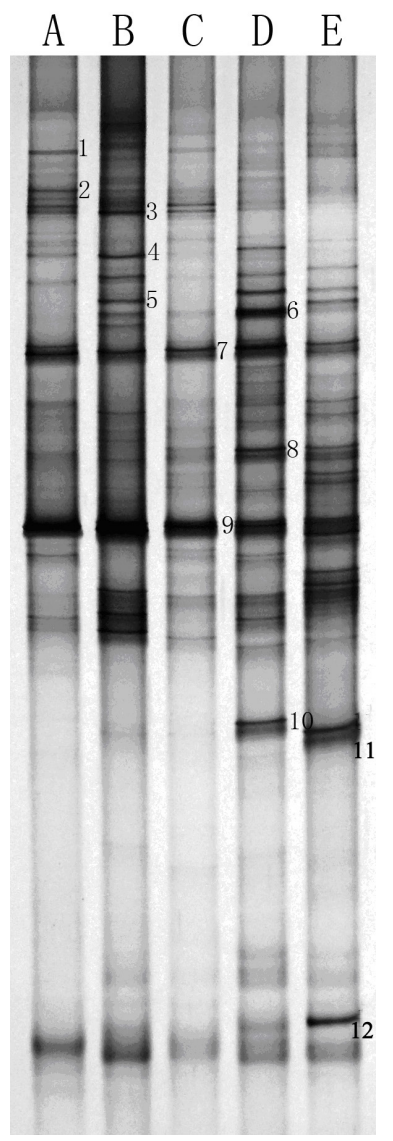

Figure 1. Denaturing gradient gel electrophoresis profiles of PCR products from fungi in potential (A), slight (B), moderate (C), strong (D), and extremely strong (E) karst rocky desertification soils. Labels indicate bands excised successfully for sequencing.
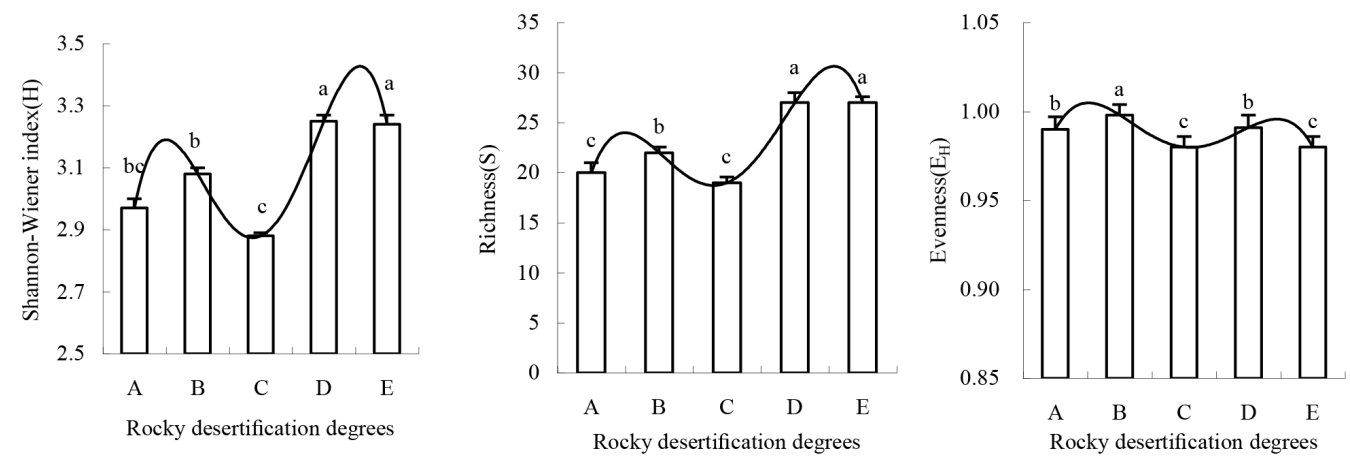

Figure 2. Genetic diversity indices of fungal communities in soils with potential (A), slight (B), moderate (C), strong (D), and extremely strong (E) karst rocky desertification. Means labelled with different letters (a-c) significantly differ $(\mathrm{P}<0.05)$.

Genetics and Molecular Research 15 (3): gmr.15038460 


\section{Similarity and cluster analysis}

Cluster analysis showed that soil fungi DGGE patterns formed two main clusters, namely, high- and low-degree KRD groups (Figure 3). The former included sites D and E, and the latter sites A, B, and C, of which A shared 61\% similarity with C, and (A, C) $57 \%$ similarity with B.

\section{Fungal community analysis and phylogenetic affiliation}

Twelve bands resulting from DGGE of amplified 18S rRNA genes from different KRD soils were excised for sequence analysis (Table 3). The phylogenetic tree constructed from partial 18S rRNA gene sequences is shown in Figure 4. The 12 DNA sequences recovered from the DGGE gel shared $96-100 \%$ sequence homology with reference sequences retrieved from the National Center for Biotechnology Information GenBank database, and two sequences shared $100 \%$ homology with characterized microorganisms such as Geomyces destructans. The fungal community in soil from site A was dominated by Geomyces (bands 1 and 2), that of B by Geomyces, Aspergillus, and Tetracladium (bands 3-5), that of C by Mortierella and Tetracladium (bands 7 and 9), that of D by Gibberella, Fusarium, and an unclassified group (bands 6,8 and 10), and that of E by Blastomyces, Aphanoascus, Mortierella, and Glomus (bands 11 and 12). Compared to site A, bands unique to KRD-affected soils (bands 3-12) were associated with Geomyces, Aspergillus, Tetracladium, Mortierella, Gibberella, Fusarium, Blastomyces, Aphanoascus, and Glomus species, and an unclassified group.

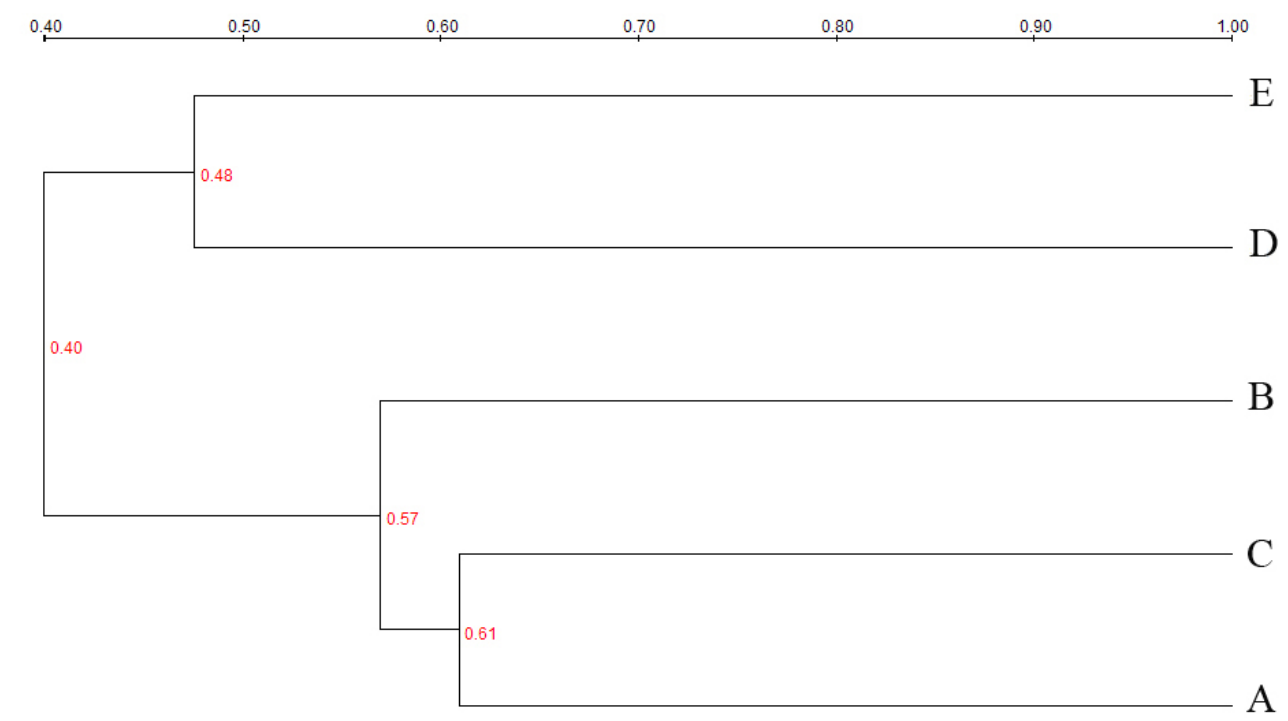

Figure 3. Cluster analysis of denaturing gradient gel electrophoresis profiles of fungi in soils affected by potential (A), slight (B), moderate (C), strong (D), and extremely strong (E) karst rocky desertification.

Genetics and Molecular Research 15 (3): gmr.15038460 
Table 3. Putative taxonomic affinities of $18 \mathrm{~S}$ ribosomal RNA gene sequences generated from selected bands of denaturing gradient gel electrophoresis soil profiles.

\begin{tabular}{l|l|l|c|l}
\hline Band & Accession No. of related sequence & BLAST match & Similarity (\%) & Putative phylum \\
\hline 1 & GU350434 & Geomyces destructans & 100 & Dikarya \\
\hline 2 & GU350434 & Geomyces destructans & 100 & Dikarya \\
\hline 3 & FJ231102 & Geomyces destructans & 98 & Dikarya \\
\hline 4 & ASNRR5SS & Aspergillus fumigatus & 98 & Dikarya \\
\hline 5 & AY204617 & Tetracladium marchalianum & 99 & Dikarya \\
\hline 6 & KF357103 & Uncultured eukaryote clone & 99 & Environmental sample \\
\hline 7 & EU736290 & Mortierella alpina & 98 & Fungi incertae sedis \\
\hline 8 & JN236216 & Gibberella intermedia & 99 & Dikarya \\
\cline { 2 - 5 } & KJ126877 & Fusarium oxysporum & 96 & Dikarya \\
\hline 9 & AY204617 & Tetracladium marchalianum & 99 & Dikarya \\
\hline 10 & AY357287 & Tumularia aquatica & 99 & Dikarya \\
\hline 11 & M63096 & Blastomyces dermatitidis & 99 & Dikarya \\
\cline { 2 - 5 } & JN941595 & Aphanoascus verrucosus & 99 & Dikarya \\
\hline \multirow{2}{*}{12} & EU736292 & Mortierella minutissima & 99 & Fungi incertae sedis \\
\cline { 2 - 5 } & FR750376 & Glomus macrocarpum & 98 & Glomeromycota \\
\hline
\end{tabular}

BLAST $=$ Basic Local Alignment Search Tool

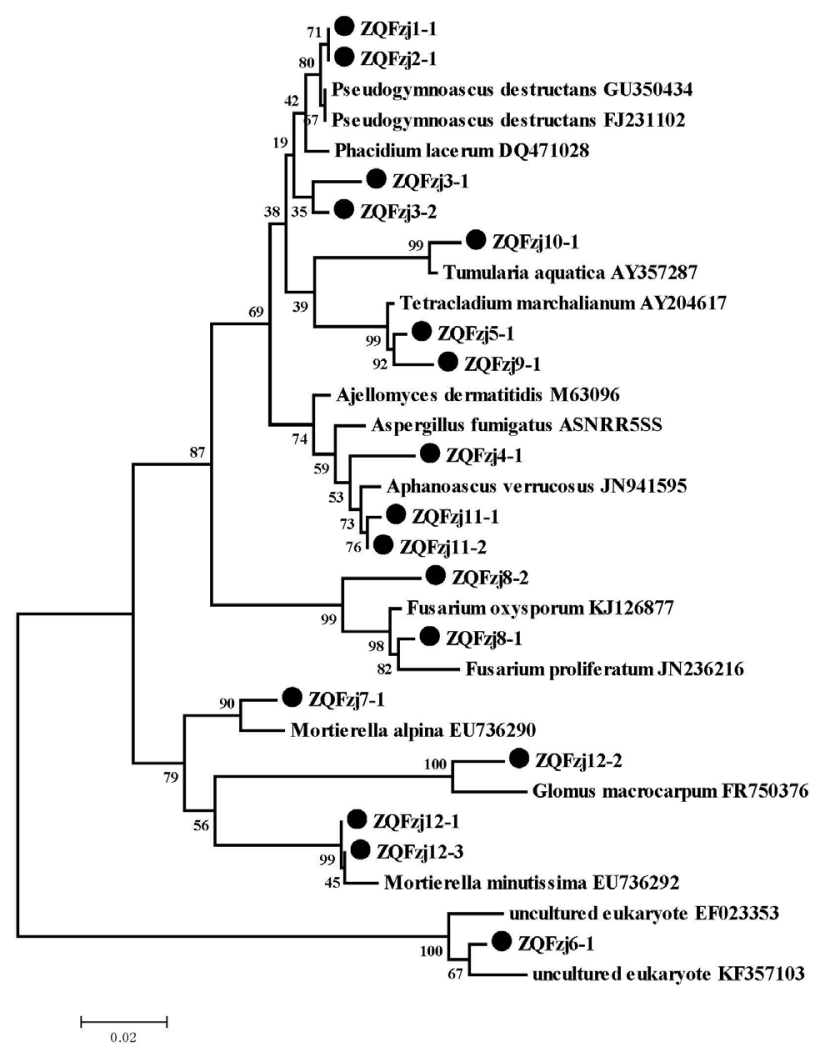

Figure 4. Maximum likelihood tree of partial 18S ribosomal RNA gene sequences from denaturing gradient gel electrophoresis bands and reference strains. Phylogenetic affiliations and accession numbers of reference strains are indicated. Bootstrap values $>50 \%$ are shown at the nodes. The scale bar represents estimated number of substitutions per site.

Genetics and Molecular Research 15 (3): gmr.15038460 


\section{DISCUSSION}

Understanding shifts in soil fungal communities under complex environmental variations is of special importance in predicting responses of ecosystems to future degradative processes (Wang et al., 2014). Karst ecosystems are subject to rapid degradation events such as deforestation, soil loss, nutrient depletion, and reduced water holding capacity, resulting in KRD that can be difficult to reverse (Huang et al., 2009; Peng et al., 2013; Tang et al., 2013). In this study, we evaluated the ways in which KRD impacts soil fungal communities. Using molecular techniques, we assessed the structure and composition of such communities across a gradient of KRD stages.

Species richness and diversity in soil fungal populations are significantly altered in forest ecosystems according to the intensity of human disturbance (Wang et al., 2014). In this study, the three fungal diversity indices demonstrated the same varying trend across degrees of KRD severity (Figure 2), being lowest in the moderately affected site. This is probably because the population sizes of many species were reduced by disturbance, but gradually became stable by the strong KRD stage. Such variation is in agreement with the shifts in fungal communities associated with vegetation elimination (Ros et al., 2009) and succession (Zhu et al., 2012). In addition, cluster analysis showed that the five sites clustered into two main groups (Figure 3), consisting of high- and low-KRD categories, indicating a great difference between the $18 \mathrm{~S}$ rRNA gene pools of the studied soils.

DGGE analyses of 18S rRNA gene fragments provide a measure of the composition and structure of the dominant species within a fungal community, and generate highly reproducible, site-specific profiles (Bossio et al., 2005). In the present study, these profiles primarily varied with regard to site, indicating that moderate KRD seems to have the strongest impact on fungal community structure, demonstrated by the least diverse DGGE pattern, with fewer bands and lower intensities. Soils exposed to strong and extremely strong KRD, on the other hand, showed DGGE bands of greater intensity and those not observed in soil from the moderate KRD site (Figure 1). These results are consistent with the findings of several other studies (Ros et al., 2009; Zhu et al., 2012). Smaller secondary influences were also found to result from differing KRD severity. We used a clone library approach to investigate the composition of soil fungi at each degree of KRD. Sequencing of DGGE bands revealed that KRD led to an increase in the proportion of some fungi (Tumularia aquatica, Blastomyces dermatitidis, Aphanoascus verrucosus, Mortierella minutissima, and Glomus macrocarpum), and a decrease in that of other common species such as $G$. destructans, compared with the site of potential KRD (Table 3). Taken together, these results suggest that KRD has a strong influence on soil fungal community structure. In addition, the unidentified group may play an important role in KRD-affected soil. However, even the functions of many well-studied genera in these ecosystems are not completely understood (Artz et al., 2007). Further investigations are required to characterize their association with karst degradation processes.

In conclusion, we have demonstrated that soil fungal communities are altered to different degrees according to KRD severity, and that this process has a negative long-term effect on such communities in karst ecosystems. Changes in fungal community composition are particularly apparent in increased KRD degrees. More importantly, shifts in the dominant fungal species are also associated with variations of KRD grade. Further investigations

Genetics and Molecular Research 15 (3): gmr.15038460 
should be carried out with a higher number of soil samples, and making use of other novel fingerprinting methods.

\section{Conflicts of interest}

The authors declare no conflict of interest.

\section{ACKNOWLEDGMENTS}

Research supported by the National Natural Science Foundation of China (\#31260572), the "973" Project of China (\#2014CB138706), and the Guizhou Project of China (Qiankeherenzi \#201502).

\section{REFERENCES}

Artz RR, Anderson IC, Chapman SJ, Hagn A, et al. (2007). Changes in fungal community composition in response to vegetational succession during the natural regeneration of cutover peatlands. Microb. Ecol. 54: 508-522. http:// dx.doi.org/10.1007/s00248-007-9220-7

Bossio DA, Girvan MS, Verchot L, Bullimore J, et al. (2005). Soil microbial community response to land use change in an agricultural landscape of western Kenya. Microb. Ecol. 49: 50-62. http://dx.doi.org/10.1007/s00248-003-0209-6

Cahyani VR, Matsuya K, Asakawa S and Kimura M (2004). Succession and phylogenetic profile of eukaryotic communities in the composting process of rice straw estimated by PCR-DGGE analysis. Biol. Fertil. Soils 40: 334-344. http:// dx.doi.org/10.1007/s00374-004-0783-x

Costa R, Gomes NCM, Peixoto RS, Rumjanek N, et al. (2006). Diversity and antagonistic potential of Pseudomonas spp. associated to the rhizosphere of maize grown in a subtropical organic farm. Soil Biol. Biochem. 38: 2434-2447. http:// dx.doi.org/10.1016/j.soilbio.2006.03.003

Darriba D, Taboada GL, Doallo R and Posada D (2012). jModelTest 2: more models, new heuristics and parallel computing. Nat. Methods 9: 772. http://dx.doi.org/10.1038/nmeth.2109

Dice LR (1945). Measures on the amount of ecologic association between species. Ecology 26: 297-302. http://dx.doi. org $/ 10.2307 / 1932409$

Dieng A, Ndoye I, Duponnois R and Baudoin E (2014). Effects of Jatopha curcas L. plantation on soil bacterial and fungal communities. Soil Biol. Biochem. 72: 105-115. http://dx.doi.org/10.1016/i.soilbio.2014.01.029

Guindon S, Dufayard JF, Lefort V, Anisimova M, et al. (2010). New algorithms and methods to estimate maximumlikelihood phylogenies: assessing the performance of PhyML 3.0. Syst. Biol. 59: 307-321. http://dx.doi.org/10.1093/ sysbio/syq010

Hagn A, Pritsch K, Schloter M and Munch JC (2003). Fungal diversity in agricultural soil under different farming management systems, with special reference to biocontrol strains of Trichoderma spp. Biol. Fertil. Soils 38: 236244. http://dx.doi.org/10.1007/s00374-003-0651-0

Huang YQ, Zhao P, Zhang ZF, Li XK, et al. (2009). Transpiration of Cyclobalanopsis glauca (syn. Quercus glauca) stand measured by sap-ñow method in a karst rocky terrain during dry season. Ecol. Res. 24: 791-801. http://dx.doi. org/10.1007/s11284-008-0553-6

Li YB, Shao JA, Yang H and Bai XY (2009). The relations between land use and karst rocky desertiðcation in a typical karst area, China. Environ. Geol. 57: 621-627. http://dx.doi.org/10.1007/s00254-008-1331-z

Liang ZB, Drijber RA, Lee DJ, Dwiekat IM, et al. (2008). A DGGE-cloning method to characterize arbuscular mycorrhizal community structure in soil. Soil Biol. Biochem. 40: 956-966. http://dx.doi.org/10.1016/j.soilbio.2007.11.016

Malosso E, Waite IS, English L, Hopkins DW, et al. (2006). Fungal diversity in maritime Antarctic soils determined using a combination of culture isolation, molecular ðngerprinting and cloning techniques. Polar Biol. 29: 552-561. http:// dx.doi.org/10.1007/s00300-005-0088-Z

Najnin RA, Shafrin F, Polash AH, Zaman A, et al. (2015). A diverse community of jute (Corchorus spp.) endophytes reveals mutualistic host-microbe interactions. Ann. Microbiol. 65: 1615-1626. http://dx.doi.org/10.1007/s13213$\underline{014-1001-1}$

Genetics and Molecular Research 15 (3): gmr.15038460 
Orlandelli RC, Alberto RN, Rubin Filho CJ and Pamphile JA (2012). Diversity of endophytic fungal community associated with Piper hispidum (Piperaceae) leaves. Genet. Mol. Res. 11: 1575-1585. http://dx.doi.org/10.4238/2012.May.22.7

Oros-Sichler M, Gomes NC, Neuber G and Smalla K (2006). A new semi-nested PCR protocol to amplify large 18S rRNA gene fragments for PCR-DGGE analysis of soil fungal communities. J. Microbiol. Methods 65: 63-75. http://dx.doi. org/10.1016/j.mimet.2005.06.014

Peng J, Xu YQ, Zhang R, Xiong KN, et al. (2013). Soil erosion monitoring and its implication in a limestone land suffering from rocky desertiðcation in the Huajiang Canyon, Guizhou, Southwest China. Environ. Earth Sci. 69: 831-841. http://dx.doi.org/10.1007/s12665-012-1968-5

Premalatha K, Gokul S, Kumar A, Mishra P, et al. (2015). Molecular profiling of fungal assemblages in the healthy and infected roots of Decalepis arayalpathra (J. Joseph \& V. Chandras) Venter, an endemic and endangered ethnomedicinal plant from Western Ghats, India. Ann. Microbiol. 65: 785-797. http://dx.doi.org/10.1007/s13213$\underline{014-0919-7}$

Qi XK, Wang KL and Zhang CH (2013). Effectiveness of ecological restoration projects in a karst region of southwest China assessed using vegetation succession mapping. Ecol. Eng. 54: 245-253. http://dx.doi.org/10.1016/j. ecoleng.2013.01.002

Rao S, Chan Y, Lacap DC, Hyde KD, et al. (2012). Low-diversity fungal assemblage in an Antarctic Dry Valleys soil. Polar Biol. 35: 567-574. http://dx.doi.org/10.1007/s00300-011-1102-2

Ros M, Hernandez MT and Garcia C (2003). Soil microbial activity after restoration of a semiarid soil by organic amendments. Soil Biol. Biochem. 35: 463-469. http://dx.doi.org/10.1016/S0038-0717(02)00298-5

Ros M, Pascual JA, Hernández MT and García C (2009). Long-term effects of devegetation on composition and activities (including transcription) of fungal communities of a semi-arid soil. Biol. Fertil. Soils 45: 435-441. http://dx.doi. org/10.1007/s00374-008-0348-5

Saikaly PE, Stroot PG and Oerther DB (2005). Use of 16S rRNA gene terminal restriction fragment analysis to assess the impact of solids retention time on the bacterial diversity of activated sludge. Appl. Environ. Microbiol. 71: 58145822. http://dx.doi.org/10.1128/AEM.71.10.5814-5822.2005

Saitou N and Nei M (1987). The neighbor-joining method: a new method for reconstructing phylogenetic trees. Mol. Biol. Evol. 4: 406-425.

Sigler WV and Turco RF (2002). The impact of chlorothalonil application on soil bacterial and fungal populations as assessed by denaturing gradient gel electrophoresis. Appl. Soil Ecol. 21: 107-118. http://dx.doi.org/10.1016/S0929$\underline{1393(02) 00088-4}$

Souza A, Cruz JC, Sousa NR, Procópio AR, et al. (2014). Endophytic bacteria from banana cultivars and their antifungal activity. Genet. Mol. Res. 13: 8661-8670. http://dx.doi.org/10.4238/2014.October.27.6

Tamura K, Peterson D, Peterson N, Stecher G, et al. (2011). MEGA5: molecular evolutionary genetics analysis using maximum likelihood, evolutionary distance, and maximum parsimony methods. Mol. Biol. Evol. 28: 2731-2739. http://dx.doi.org/10.1093/molbev/msr121

Tang YQ, Li J, Zhang XH, Yang P, et al. (2013). Fractal characteristics and stability of soil aggregates in karst rocky desertification areas. Nat. Hazards 65: 563-579. http://dx.doi.org/10.1007/s11069-012-0383-2

Wang M, Shi S, Lin F and Jiang P (2014). Response of the soil fungal community to multi-factor environmental changes in a temperate forest. Appl. Soil Ecol. 81: 45-56. http://dx.doi.org/10.1016/j.apsoil.2014.04.008

Wu XQ, Liu HM, Huang XL and Zhou T (2011). Human driving forces: analysis of rocky desertification in karst region in Guanling County, Guizhou Province. Chin. Geogr. Sci. 21: 600-608. http://dx.doi.org/10.1007/s11769-011-0496-7

Xiong K, Li P, Zhou ZF and Lan AJ (2002). The RS and GIS representative study on karst rock desertiðcation-an example of Guizhou Province. Geology Press, Beijing.

Yan Y, Wolkers-Rooijackers J, Nout MJ and Han B (2013). Microbial diversity and dynamics of microbial communities during back-slop soaking of soybeans as determined by PCR-DGGE and molecular cloning. World J. Microbiol. Biotechnol. 29: 1969-1974. http://dx.doi.org/10.1007/s11274-013-1349-6

Yang QY, Jiang ZC, Ma ZL, Luo WQ, et al. (2013). Relationship between karst rocky desertiðcation and its distance to roadways in a typical karst area of Southwest China. Environ. Earth Sci. 70: 295-302. http://dx.doi.org/10.1007/ $\underline{\text { s12665-012-2127-8 }}$

Yoshitake S, Fujiyoshi M, Watanabe K, Masuzawa T, et al. (2013). Successional changes in the soil microbial community along a vegetation development sequence in a subalpine volcanic desert on Mount Fuji, Japan. Plant Soil 364: 261272. http://dx.doi.org/10.1007/s11104-012-1348-7

Yu J, Zhou XF, Yang SJ, Liu WH, et al. (2013). Design and application of specific 16S rDNA-targeted primers for assessing endophytic diversity in Dendrobium officinale using nested PCR-DGGE. Appl. Microbiol. Biotechnol. 97 : 9825-9836. http://dx.doi.org/10.1007/s00253-013-5294-y

Genetics and Molecular Research 15 (3): gmr.15038460 
Zhang PP, Hu YM, Xiao DN, Li XZ, et al. (2010). Rocky desertification risk zone delineation in karst plateau area: a case study in Puding County, Guizhou province. Chin. Geogr. Sci. 20: 84-90. http://dx.doi.org/10.1007/s11769-010$\underline{0084-2}$

Zhang W, Long X, Huo X, Chen Y, et al. (2013). 16S rRNA-based PCR-DGGE analysis of actinomycete communities in fields with continuous cotton cropping in Xinjiang, China. Microb. Ecol. 66: 385-393. http://dx.doi.org/10.1007/ s00248-012-0160-5

Zhao J, Wu X, Nie C, Wu T, et al. (2012). Analysis of unculturable bacterial communities in tea orchard soils based on nested PCR-DGGE. World J. Microbiol. Biotechnol. 28: 1967-1979. http://dx.doi.org/10.1007/s11274-011-0999-5

Zhou J, Tang YQ, Zhang XH, She TY, et al. (2012). The influence of water content on soil erosion in the desertification area of Guizhou, China. Carbonates Evaporites 27: 185-192. http://dx.doi.org/10.1007/s13146-012-0104-7

Zhu HH, He XY, Wang KL, Su YR, et al. (2012). Interactions of vegetation succession, soil bio-chemical properties and microbial communities in a Karst ecosystem. Eur. J. Soil Biol. 51: 1-7. http://dx.doi.org/10.1016/j.ejsobi.2012.03.003

Genetics and Molecular Research 15 (3): gmr.15038460 